\title{
WHY THE CRITICS OF GLOBALIZATION ARE MISTAKEN*
}

\author{
BY
}

\author{
JAGDISH BHAGWATI**
}

Key words: globalization, trade

JEL Code(s): F02, F1

\section{INTRODUCTION}

Being invited to give the Tinbergen Lecture is a privilege for any economist. But for me it is also a great pleasure as it brings back to me memories of, not just a great economist who won the first Nobel prize in Economics, but of a great humanist whose example affected me deeply.

I first met him in Cambridge, Massachusetts, when I was a student at MIT and he was a Visiting Professor at Harvard. He was kind enough to invite me, among other students, to his home for dinner. I recall his saying, with a sense of puzzlement rather than deprecation, that many of his Harvard students had come to him just before the final examination, and had asked him: When you put down dy/dx, why don't you cancel out the 'd'? Well, that could not have been a question asked by MIT students! Perhaps that was why, when Professor Paul Samuelson, my teacher and then colleague and now friend, wished us to understand why the Stolper-Samuelson theorem worked because the tradeinduced reallocation of resources changed the capital/labor ratios in both goods in the same direction, he said: imagine that the worst student at MIT flunks out and joins Harvard; the average IQ in both MIT and Harvard goes up.

But my next meeting was more dramatic. I had gone as a youthful OECD "consultant" to work for 3 months in the Devlet Planlama Teskilati, Turkey's Planning Commission, in 1962. There I was, staying at a posh hotel, earning

\footnotetext{
* This is the final text of the Tinbergen Lecture delivered to the Royal Netherlands Economic Association in Amsterdam in October 2006. The author is University Professor, Economics and Law, Columbia University, and Senior Fellow in International Economics at the Council on Foreign Relations. His latest books, Free Trade Today (Princeton, 2002) and In Defense of Globalization (Oxford, 2004) present the economic case and the social case for globalization and for free trade, respectively in far greater depth than a Lecture permits. Some of the arguments in this Lecture will be developed further in a substantial Afterword to the new edition of In Defense of Globalization that will be issued in the Summer of 2007 by Oxford University Press.

** Department of Economics and Law, Columbia University, 828 International affairs Building MC 3308, 420 west $118^{\text {th }}$ street New york, NY 10027 USA

e-mail: jb38@columbia.edu
} 
an indecent salary that vastly exceeded my experience and policy competence, when Professor Tinbergen arrived to help the Planning Commission. He stayed in a modest hotel; and I was told that he was charging no consulting fee. He was there, quite simply, to do good. For him, development of the poor countries was a vocation, not a profession. I resolved then to emulate him; and indeed, while like him I have earned my reputation through scientific work, I have spent much of my career, also trying to do good. Indeed, the scientific scholarship must precede the ability to influence policy in the diverse ways that one can today. As Bertrand Russell once said: unless you have written what almost no one can understand, you cannot write what everyone can understand. Quite simply, no one who matters will read you if you do not have the scientific reputation to give you the credentials.

My last memory of Professor Tinbergen was in Netherlands itself. I was awarded an Honorary Degree at the 75th Anniversary celebration of Erasmus University: a wonderful event where the Rectors of many Scandinavian countries were in attendance. Professor Loet Mennes had organized a scientific conference in my honor; and Professor Tinbergen came in an act of kindness and friendship. I now treasure a splendid photograph of him and me in conversation at that conference. ${ }^{1}$

I am certain that, if he were alive today, he would be deeply involved in the great debates over Globalization in which we find ourselves. So, I have decided to address the issues that the anti-Globalization critics have raised, since they dominate much of the public space, particularly in the rich countries. I wish to argue that the critics of Globalization are mistaken.

To respond adequately to the critics of Globalization, however, it is useful to recall what Rabbi Hillel, who lived in the time of Herod, said: "If I am not for myself, then who will be for me? And when I am only for myself, what am I?" (He did go on to add: "And, if not now, when?," a prescription that has less appeal, I am afraid, to many who would rather follow St. Augustine who famously said: "Dear God, grant me chastity, but not yet").

What the Rabbi was saying was that we have, or must have, both altruism and self-interest to define our lives. But, in truth, on this spectrum, few lie in the center but tend to gravitate towards one end or the other. And this is just what we find among the critics of Globalization. Several are altruistic; they proceed from empathy, thinking that Globalization is malign in its impact on humanity, on what might be called "social issues." But a large number are also proceeding instead from self-interest, actuated by fear. These include mainly the labor unions that fear their wages and standards will collapse with Globalization, and others who fear that the overall prosperity of their nation is also at risk.

As it happens, both sets of critics are mistaken; and so let me treat each separately, starting with the criticisms based on altruism and empathy, where

1 It is on my website www.columbia.edu/ jb38. 
I will conclude that, instead of lacking a Human Face, Globalization Has a Human Face.

\section{ALTRUISM AND EMPATHY}

In May 2004, I published my book, In Defense of Globalization (Oxford), addressing the questions raised by the critics of Globalization. Since my distinguished colleague Joe Stiglitz (who, I notice, has also given the Tinbergen Lecture) had written in 2002 his book, Globalization and Its Discontents, which was inevitably contrasted with mine, I was repeatedly asked whether mine was a riposte to his. When I was in Mexico, for instance, at a big seminar on Globalization soon after, I was told from the floor that Professor Stiglitz had just been through and was my Lecture prompted by his? I answered that my radical teacher Joan Robinson, when she had heard that Milton Friedman had been through many Indian campuses, had gotten hold of his itinerary and had followed it from campus to campus so as to undo the damage done by Friedman. I added that, as it happened, I was not even aware that Stiglitz had just talked in Mexico City and my visit was entirely unrelated to his, but now that I happened to be following him, I would certainly use the opportunity to undo the damage he was busy inflicting on the Mexicans and indeed worldwide. ${ }^{2}$

My book, in any event, dealt uniquely with the "social impact" questions which the young students and the civil society groups were raising. It was prompted by the WTO Ministerial Meeting in November 1999 when the attempt at launching the first WTO Round of multilateral negotiations sank under the onslaught of massive demonstrations and disruptions matched by the Clinton Administration's lack of preparation to confront and contain the mayhem. As I debated civil society leaders, including Ralph Nader in the Town Hall, and appeared on the opening Panel for NGOs (which had to be postponed to the afternoon because of a bomb threat) with Pascal Lamy, Clare Short, Charlene Barshefsky, Alec Erwin and other Trade Ministers, and then talked with the demonstrators on the streets, I felt that these were not people who were worried about whether Free Trade was good for aggregate GNP and prosperity or whether Protection was more appropriate.

Rather, they were concerned with what might be called the social implications of economic globalization. They were concerned, indeed were convinced, that Globalization put us behind on several "citizens' issues" such as the environment, indigenous culture (a la President Evo Morales) and

2 It is astonishing how easily a Nobel Prize can be used as a weapon of mass destruction in countries where populists are looking for any well-known economist to be cited, no matter whether he knows anything about the subject, to make their assertions credible to the population at large, and where often the local elites have little scientific knowledge to challenge such economists. 
mainstream culture (a la Monsieur Bove), democracy, poverty in the poor countries and child labor there as well. To use the phraseology that Bill Clinton, Gerhard Schroeder and Tony Blair made fashionable, they claimed that Globalization Lacks a Human Face. But was this true?

My 2004 book was precisely addressed to this overriding issue. Before analyzing this issue, however, I tried to understand what had brought about the remarkable growth of altruistic concerns, much of it from the idealistic young. I found the explanation largely in what I called the "inversion of Hume's concentric circles". David Hume and Adam Smith were both members of the Scottish Enlightenment. Both had written how distance diminished empathy. In a classic passage, Adam Smith had written in The Theory of Moral Sentiments in 1760 that a European man of sensibility would continue to snore through the loss of a hundred million Chinese in an earthquake "provided he never saw them" but "if he was to lose his little finger to-morrow, he would not sleep to-night." David Hume had written of concentric circles of empathy which declined as one went further from the center. Today, however, we have the death of distance; and television brings ever closer to us the hitherto-hidden pestilence, famine and tragic afflictions of the countless in misery. At the same time, as the political scientist Robert Putnam has argued, there is increasing tendency for civic life to decline in communities, that Americans in particular no longer "bowl together." So, the outermost circle has become the innermost circle, whereas the innermost circle is now beginning to be the outermost circle. The idealist young therefore are agitated and animated by the afflictions that they witness close at hand today; and they cry out for solutions, which they often find in anti-globalization rhetoric and advocacy.

By looking at virtually every social concern I could lay my hands on, I argued that Globalization, by and large, advanced these social agendas instead of handicapping them. In short, Globalization Has a Human face. I can only hint at the kinds of argumentation and evidence that I marshaled to arrive at this startling conclusion.

Thus, take the wage differential against women. Take the phenomenon that, for the same type of work and the same qualifications, a firm pays men more than women. Using Gary Becker's theory of price and prejudice, we may hypothesize that the willingness of firms to pay more for equally qualified men will begin to shrink once they face stiff international competition. So, in traded industries, you would see the wage differential closing faster than in non-traded industries. Lo and behold, that is just what two splendid women economists, who did their dissertation at Harvard some years ago, found to be the case in US over a long period. Globalization, in the shape of trade, was a force for good, not harm.

But take the differential in pay that comes, not at the level of the firm, but because women traditionally have been confined to jobs that pay less: like teaching and nursing. But even here, take the example of Japanese 
multinationals. In Japan the glass ceiling beyond which women cannot go used to be so low that women could barely stand up! One went to Japan and found that, in a land that produced the world's first great female novelist Lady Murasaki in 11th century, today the women typically were either housewives or in jobs such a bringing tea while the men who were executives talked and negotiated. When Japanese multinationals started going abroad in massive numbers in late 1980s, the men of course remained executives. But their wives who lived in New York, Paris, Rome and London, suddenly saw how Western men treated their wives differently and how the women were upwardly mobile in business and other occupations. That turned them into powerful agents of change when they returned. And so now we have had Madame Ogata as the UN High Commissioner for Refugees, Madame Tanaka as the Foreign Minister and many women getting into the Diet and also rising in executive ranks. Japanese investment abroad was among the phenomena that fostered the change in attitudes that led to the promotion of equality for Japanese women. ${ }^{3}$

I might simply add one more vignette from my Globalization book, since that is also an area where the critics get things exactly wrong. This relates to whether Globalization in the shape of trade and multinationals helps reduce child labor in the poor countries, or accentuates the phenomenon. Suppose that the removal of trade barriers, whether one's own or foreign, leads to trade expansion and hence to increased incomes: as much evidence shows. The question then is: will parents be wicked and say: now that we can make more money through exports, we will take the fifth child out of school and out her into work; or will they act as virtuous parents who will instead say: now that we have more income, we will take the fifth child out of work and put her into school instead? As it happens, economists often talk about incentives rather than values

And this too reinforces the argument in favor of parents being virtuous. Why? Because, many studies show that the economic returns to primary education are high but that, in the absence of perfect credit markets, poor parents cannot borrow to send their children to school even when profitable. In short, when parents are credit-constrained, the infusion of extra cash through

3 This trend has also been helped by the increasing flow of Japanese students to the West, where they learn our way of life and our values. Thus, the early Japanese students used to be deferential and called me "sensei," the revered teacher: I sometimes joke that I used to love it as no American students would ever do that! But now, they put their feet on the table like the American students and even blow those horrid bubbles from their chewing gums. This "acculturation" of Japan is a gathering force that shows itself up in several ways. I have described the phenomenon by titling a 1994 Foreign Affairs article of mine, on the US-Japan trade negotiations where the Japanese refused to accept demands for import targets, "Samurai No More": our negotiators thought they were dealing with the samurai when in fact they were dealing with GIs. Another apt metaphor is: "Crossing Against the Light": whereas the traditional Japanese dutifully waited for the green traffic light to flash before they crossed a road, now they are like New Yorkers dashing across despite red and yellow lights. 
Globalization will enable the parents to send more children to primary schools than to farm work. The evidence, from many empirical studies, surveyed in Chap. 6 of my Globalization book, shows precisely that. And some of the studies show that the shift to schooling benefited girls as well, yielding a double dividend.

\section{SELF-INTEREST AND FEAR}

But if the concerns about Globalization that proceed from altruism and empathy can be laid to rest, those arising from self-interest and fear are not so easily dismissed, though they are even less grounded in objective reality.

The fear of trade and multinationals today particularly afflicts the rich countries, where many are afraid that economic prosperity is imperiled by trade with the poor countries and additionally the working classes and the unions typically fear that their wages and standards are in peril from trade with the poor countries - it was only a few decades ago that the fear was rampant among the poor countries that the poor countries were in such peril from trade with the rich countries: how ironic this seems. But a few economists (the principal one being Stiglitz) and some cash-rich NGOs (principally Oxfam which seems to have been misled in turn by Stiglitz) have worked hard to renew the fear among the poor countries as well. Let me therefore urge you to read the extended analysis and empirical evidence that I have produced, on the benefits of trade for prosperity in the poor countries, in Chap. 5 of my book, and on the need to discount the alleged adverse effect of trade on wages and labor standards in the rich countries, in Chap. 10 of the book. But let me add a few salient points here, on the question of the relationship between trade and prosperity, while dealing with the question of wages and labor standards more robustly later. I will also start with conventional worries; and then I will address worries (such as the fear of India and China) that have emerged in recent years, reinforcing the old concerns, in regard to both overall prosperity and wages.

\subsection{Prosperity from Trade}

First, my colleague Professor Arvind Panagariya has noted that, if one examines the growth and trade record (where available) of rich and poor countries for nearly forty years in the postwar period, you see a remarkable phenomenon. The "economic miracle" countries which averaged a high annual growth rate of per capita income at about 3\%, also showed similar growth in their trade; and the "economic debacle" countries that experienced negligible or even negative growth rates were also characterized by similarly dismal trade 
performance. ${ }^{4}$ Now, this does not necessarily imply that trade led to growth instead of the other way around.

But anyone who has studied the experience of developing countries in depth knows, and I know because I have participated in two major projects (one where I was a country co-author and one which I co-directed) in 1960s and 1970s of trade and development policies of several countries, the argument that growth happened independently of trade, which simply followed as a "trickle-down" effect of growth, is little short of crazy. ${ }^{5}$ But this area does invite entry by crazy people

Or it attracts people who are not crazy but act as if they were because the market incentives are such today that they reward craziness. It is tempting to think that the few dissenters on the efficacy of trade in promoting prosperity are like the dissenters such as Vaclav Havel who were persecuted in the erstwhile communist countries. But our trade and globalization dissenters lead very comfortable lives instead because their dissent gets amply rewarded. The answer lies in the economics of value. If there are only two of you (say Stiglitz and Rodrik) and all economists are on the other side, your scarcity value is immense. You are on the plane to Oslo, Mumbai, Tokyo, indeed every exotic place that is holding a Conference on Globalization and is looking for an anti-Globalization voice!

Second, note that it is possible to observe periods, which may last over almost two decades in rare cases, where autarky and high growth rates may be observed together. But it is impossible to find cases where this has been a "sustainable" relationship over very long periods. The Soviet Union collapsed after making many economists, including me at one stage, believe that its autarky was no barrier. Well, just look at a chart on Soviet Russia's steadily declining growth rate in the face of huge investment rates ${ }^{6}$ after a huge spurt in 1920 s and 1930s, and you see that declining productivity that must partly be attributed to a virtually closed economy and additionally to the rigidity of central planning laced with massive restrictions on production and investment that finally caught up with those folks.

But let me also tell you a funny, and true, story about my Cambridge teacher Joan Robinson. Long ago, when Jan Myrdal was writing his remarkable Report from a Chinese Village (1965), she and Gus Ranis of Yale, one a radical and the other a mainstream economist, were overheard agreeing that Korea was an economic miracle. How could this harmony have arisen? It

4 See Arvind Panagariya, "Miracles and Debacles: In Defense of Trade Openness", The World Economy, Vol. 27(8), August 2004, pp. 1149-71.

5 I use the word "crazy," which is not very polite, in the tradition of Keynes who wrote famously that it would be crazy to prefer bilateral trade agreements to multilateralism in trade. 6 See, for instance, the Chart on the Soviet growth rates in Padma Desai's Introductory Chapter in her Soviet Economy: Problems and Prospects, Basil Blackwell, Oxford, 1987; Chart 1.1. 
turned out that she was thinking of North Korea whereas Ranis was talking about South Korea. Now, after over a quarter of a century, we know who was right: North Korea simply failed to sustain its high growth rate. Autarky, and total lack of political and economic freedoms, turned the short-run miracle into a debacle. ${ }^{7}$

Third, much is made these days of the cliché that "one (shoe) size does not fit all," implying that general advice that trade is good is unsound and that we must vary the prescription with each country, presumably advocating protection here and there, on an ad hoc basis, and without an overarching philosophy that progress toward freeing trade was desirable. This sounds so right; but it is downright shallow and silly. Science, and good policy, require that certain general propositions be taken as guiding principles, as distinct from reliance on ad hoc prescriptions. One has to decide whether one wants to go barefoot or wear shoes. And once one decides to wear shoes, the shoe size will inevitably tend to vary, as the policy gets grounded in reality. Thus, one has to decide whether the central policy has to be openness or autarky. After the postwar experience, clearly good policymaking requires a policy of freer trade. But this does not mean that the actual freeing of trade must not take into account the political and economic difficulties that may attend the transition from one system to another: the transition to freer trade, and working with an open economy, require policy and institutional support that have in fact been the subject of rich analysis by trade economists for decades. ${ }^{8}$

\subsection{Globalization: Trade, Immigration and Wages}

The long-standing stagnation, or at best very sluggish rise, in worker's earnings in US has given rise to the fear that Globalization, involving trade with the poor countries and also illegal unskilled immigration from them, is at the

7 There is consensus now that the cocktail made with three liqueurs - greater reliance on markets, political democracy, and openness to the world economy - is enormously productive of prosperity and hence of attack on poverty. Both Soviet Union and North Korea rejected the cocktail, foregoing markets, denying democracy and embracing autarky. In this regard, see also the discussion in my 1993 Rajiv Gandhi Memorial Lecture, Democracy and Development, reprinted in my essays, A Stream of Windows, Cambridge, MA, MIT Press 2000.

8 In fact, I and other trade economists began writing about the rationale for, and design of, adjustment assistance in import-competing industries in 1970s. I have often lectured also about the need to remedy the absence of such a safety net in the poor countries, which had generally been exempted from reciprocity requirements at the GATT under the Special \& Differential Treatment provisions, and therefore were not liberalizing and hence had traditionally little need for the safety net. Now that they have seen the benefits of trade liberalization, and would like to profit from trade liberalization, many are fearful to move on to the high wire when there is no safety net. 
heart of the problem. Yet, this causation is hard to take at face value, no matter how plausible it seems to many in the rich countries.

First, all empirical studies, including those done by some of today's top trade economists (such as Paul Krugman and Robert Feenstra), show that the adverse effect of trade on wages is not substantial. My own empirical investigation, reported also in Chapt. 10 of my Globalization book, in fact argues that the effect of trade with poor countries may even have been to moderate the downward pressure on wages that rapid unskilled-labor-saving technical change would have caused. ${ }^{9}$

Second, the same goes for the econometric studies by the best labor economists today, regarding the effects of influx of unskilled illegal immigrants into the United States. The latest study by George Borjas (no friend of illegal immigrants) and Larry Katz, both of Harvard, once necessary adjustments are made, also shows a virtually negligible impact on US workers' wages.

So, despite the popular fears, Globalization does not appear to be the cause of the problem. What then explains the disturbing situation regarding wages? Can it be that Globalization has significantly reduced the bargaining ability of workers and thus put a downward pressure on wages? I strongly doubt this. First, the argument is not relevant when employers and workers are in a competitive market and workers must be paid the going wage. As it happens, only under $10 \%$ of the workers in the private sector in the US are now unionized. Second, if it is claimed that acceleration in Globalization has decimated unionization, that is dubious. The decline in unionization has been going on for longer than the last two decades of Globalization, shows no dramatic acceleration in the last two decades, and is to be attributed to the union-unfriendly provisions of the half-century-old Taft-Hartley provisions that crippled the ability to strike. Third, it seems plausible that unionization has also suffered because fewer workers now expect that unions can deliver higher wages. In the public sector, the wages are squeezed because of budget constraints: as the recent NY Transit strike showed, the public utilities are increasingly unable to raise the price of services or to get more subsidies to finance losses and therefore the ability of unions in such a situation to get more for their workers is crippled. Again, increasing numbers work at home, in no small measure due to technical change such as on-line transactions, that facilitates such decentralized work, in a return to the pre-factory-work era, and are therefore less amenable to unionization.

Again, can we turn to yet another element of Globalization for an explanation? Has the outflow of Direct Foreign Investment (DFI) to the poor countries with cheap labor caused a decline in the capital which works at

9 This is also the conclusion of Robert Feenstra and Gordon Hanson, reviewed in my book, in their study of outsourcing of components to Mexico from US and its effects on US wages. While the wage differential between skilled and unskilled workers rises, the real wage of the unskilled rises as well. 
home with unskilled labor and hence to a decline in wages? But, as I look at the data, US has received more or less as much equity investment as it has lost over the last two decades. One cannot just look at one side of the ledger; I might add that $I$ was once in a $\mathrm{BBC}$ radio debate with the Mayor of the French town which had lost its Hoover factory to England. He was lamenting the loss and holding up multinationals as somewhat wicked in their pursuit of profits. So, I told him: Mr. Mayor, Hoover is an American firm. When it came to your town, you applauded. Now that they have traveled on, you are agitated. You cannot have it both ways. Again, I often recall the remarkable example of Route I-95 going through the Carolinas in US. Along a stretch, several jobs have been lost in textiles which have now traveled further south or to other countries. But then, many German firms have come in, offsetting this outflow. That segment of I-95 is now called the Autobahn! Indeed, as I argue below, the econometric evidence on location by multinationals does not show that cheap labor is a big draw; and many other factors producing competitiveness are at play, making the rich countries a major player and attraction in the inflow of equity investments by multinationals.

So, in lieu of Globalization as the culprit, one has to fall back on the argument that substantial unskilled-labor-saving technical change is putting pressure on the wages of the unskilled. Technical change (except for the Green Revolution where the new seeds led to an increased demand for landless labor and to increase in their real wages because the use of irrigation and fertilizers with the new seeds led to more intensive use of land through multiple shifts) happens to be continually economizing on the use of unskilled labor. Much empirical argumentation and evidence exists on this, coming from world-class economists such as Alan Krueger of Princeton. But, as always, anecdotes (which obviously cannot substitute for systematic evidence) can make this point come alive. ${ }^{10}$

The effect of technical change in increasing the demand for skilled and reducing that for unskilled, labor today can be illustrated by two examples.

First, to take an example from my own, Professorial life, secretaries are increasingly hard to get from the university administration on campuses. Instead, universities now offer you computers. Whereas secretaries are generally semi-skilled - though highly educated and gifted females often did become secretaries because they had few other options because of traditional

10 The use of anecdotes and bon mots is a device for making abstruse economic arguments accessible and plausible to the public at large. Wit, irony and even sarcasm are excellent aides in putting one's points across to the public at large. I might also add that there is now a fetish, among even serious economists like Dani Rodrik, Jeffrey Sachs and Robert Barro (all associated with Harvard University, strangely enough), for mindless cross-country regressions which serve as a substitute for analysis. The use of these regressions as "evidence," and the pretense that they are superior to, and a desirable substitute for conceptual and analytical arguments - Dani Rodrik once described conceptual analysis as "rhetoric" and his regressions as "evidence," committing two errors in one breath - are increasingly coming under fire. 
role-playing that militated against their working in the higher-paid occupations - the computers have to be looked after, and frequently fixed for failure (especially when one has a deadline) by "electronic plumbers" who are skilled and get paid much more. So the rapid spread of computers is steadily reducing demand for secretaries and increasing the demand for the electronic plumbers.

A more striking example comes from Charlie Chaplin's famous film, Modern Times. You will recall how he goes berserk on the assembly line, the mechanical motion of turning the spanner finally getting to him (in a throwback to Adam Smith's famous observation that the division of labor, and concentration on repetitive, narrow tasks could turn workers into morons and that education for them had to provide the antidote).

Suppose that you take your child to see the film and she asks you: Daddy, take me to see an assembly line so I can actually see the people working at it. Well, it is going to be increasingly difficult to find such an assembly line for your child to see. Yes, there are assembly lines today; but they are without workers; they are managed by computers in a glass cage above, with highly skilled engineers in charge. The disoriented Charlie Chaplins have increasingly disappeared, at least from the assembly lines. Amusingly, this was brought home to Americans when, having decided to investigate the production of potato and semiconductor chips because of the widespread perception that potato chips (much like in the days when they were made by one's mother in the kitchen before cholesterol-consciousness arrived to kill such indulgence) were produced by primitive techniques and semiconductors were made with advanced technology, a reporter found that the facts were the other way around. He visited a factory that produced semiconductors and found that it involved moronic fitting of little wires onto small boards, whereas the Pringles factory he visited for potato chips was fully automated on its assembly line, with Pringles fitting beautifully on one another, each a total replica of the other, in the red and green boxes one finds in mini-bars in hotels.

The facts are that this is rapidly occurring in US, and in other rich countries, as technical change is quickly spreading through the system. This naturally creates, in the short-run, pressure on the jobs and wages of the workers being displaced.

But we know from past experience with technical change that we usually get a J-curve where, as productivity increase takes hold, it will (except in cases where macroeconomic difficulties may occur and are not addressed by macroeconomic remedies) get to increase the wages: so that a Luddite response is hardly called for. So, why has there been no such effect, at least a significant effect, in the statistics on wages for almost two decades?

I suspect that the answer lies in the intensity of displacement of unskilled labor by IT-based technical change - its potency is dramatic, as is evident from daily experience of nearly everyone - and in the fact that it 
is continuous now, unlike discrete changes like the invention of the steam engine. So, before the workers get on to the rising part of the J-curve, they run into yet more such technical change, so that the working class gets to go from one declining segment of the J-curve to another, to yet another. The pressure on wages gets to be relentless, lasting over longer periods than in earlier experience with unskilled-labor-saving technical change. But this technical change, which proceeds like a tsunami, has nothing to do with Globalization.

\section{NEW ARGUMENTS RAISING FEAR OF GLOBALIZATION}

Recently, however, there have been renewed fears of Globalization that need to be addressed. They come from, and not wittingly, from most unlikely sources. One is paradoxically from the greatest economist alive today, Paul Samuelson, a proponent of free trade; the other comes from the prolific pro-Globalization journalist Tom Friedman.

\section{THE SAMUELSON QUESTION}

Writing in the Journal of Economic Perspectives, Professor Samuelson chided the proponents of Globalization as failing to realize that external changes, such as the growth of China and India, could diminish the gains from trade and hence be harmful. He is doubtless right that external, exogenous changes can harm; equally, they can help. Imagine you are in Miami and the hurricane arrives, creating devastation. But you can also imagine that in India, the monsoon is good and leads to an abundant harvest. Trade economists have long discussed the likelihood of these opposed possibilities. The issues were at the forefront during the years of the Dollar Shortage after 2nd World War when Europeans thought that external, exogenous growth of US productivity was a source of pressure on European incomes and the exchange rate. The downside possibility resurfaced in 1980s when the fear of a rising Japan created similar fears in US. Now, the rise of India and China has resurrected similar fears. Will their accumulation of capital and of know-how reduce our gains from trade since we specialize in producing and exporting goods that use skills and capital intensively?

Professor Samuelson is dead right in raising this question; perhaps in the public debate on Globalization, this possibility has been downplayed. But where he was misinterpreted widely is in the assumption that, when gains from trade diminish because of such exogenous changes abroad, the policy response must be to abandon free trade and to embrace protection. Take the Miami example. If its response to the devastation from the hurricane is to shut off trade with the world, the anguish of its citizens will only worsen. It is astonishing, but not surprising, how the protectionists flocked to him, a free trader, with no comprehension of Samuelson's argumentation, arguing 
that the world's most eminent economist had "conceded" that free trade was problematic.

But then, if he certainly does not advocate protectionism, Samuelson does raise the question which bothers many who fear the rise of India and China and the effect of this, if not on our wages, at least on our economic prosperity. For, if the gains from trade diminish, that does mean reduced prosperity. But here, let me say that there are reasons to think that his downside scenario is not likely.

To see this perhaps most clearly, get back to the argument that, as India and China (the chief among the developing countries who strike fear in this regard) accumulate capital and know-how, i.e. as the rich countries and the erstwhile poor countries get to be "more similar" in their factor endowments, the gains from trade will diminish because the rich countries' exports will fall in price. But what happens, in fact, as countries get similar? Trade now breaks out in "similar goods"; what we economists call "intra-industry trade" grows.

Yet another way of putting it is to say that trade in "variety" breaks out.

You can see it in the fashion trade, for example. Walk down Madison Avenue in New York, for example, and you see, cheek by jowl, Georgio Armani, Calvin Klein, Pierre Cardin, Yves St Laurent and Kenzo competing and coexisting: none, incidentally, seeks protection from its "home country." There is much trade in similar products, with producers across countries often at different places on the spectrum of products that we call an industry.

But we have not merely casual empiricism on the issue. Pioneering empirical work by my MIT student Robert Feenstra, and by my Columbia colleague David Weinstein, has demonstrated that these gains from similar products are huge today. Once this is factored in, Professor Samuelson's fears of the downside to our prosperity from the rise of China and India seem implausible. ${ }^{11}$

\section{TOM FRIEDMAN: THE EARTH IS NOT FLAT}

Yet another source of recent worries about the risk to the rich countries from the rise of India and China has come from Tom Friedman's latest book, The Earth is Flat which, despite critical reviews in The Financial Times and in The Economist (which said with a display of good taste that it was better to read my Globalization book instead, a recommendation that they repeated in the course of an uncomplimentary review of Stiglitz's second and even more unsuccessful attempt at writing on Globalization), has been a bestseller for months.

Friedman essentially conjures up a vision where he has these countries, with high technology and low wages, come marching down a flat road like

11 Assar Lindbeck, in his recent writings on China, has also argued plausibly that even traditional trade, and not just trade in variety, can be confidently expected to grow between China and India, on the one hand, and the rich countries of today. 
Russell Crowe's Roman legions and take every job away from the rich countries. He often quotes the remarkable entrepreneurs in India's Silicon Valley in Bangalore, who say, quite correctly: we can do anything that Americans can do, which is no idle boast. But the reader translates that as the altogether different and erroneous proposition: Indians will therefore wind up doing everything that the Americans presently do. The latter scares the hell out of Americans. But it abolishes the notion of comparative advantage and therefore it is totally wrong.

Let me put this criticism in a way that you can see at once. Do we really have a flat road? What ever happened to potholes and to mountains that the road has to skirt around or tunnel through? Take just two examples as to why countries do not travel on the same flat road. Take China and India. Both countries have dramatically improved their growth rates, and their poverty, by abandoning the old policy framework that included autarkic attitudes to Globalization regarding trade and inward direct equity investments. You would expect them to have similar performance levels in modern sectors like IT software. But India is way ahead on it. Why? The answer surely lies in the differential politics of India and China. Democratic India rejoices in IT software and already is a major force in world commerce in it. But authoritarian China is fearful of the seditious implications of letting free information flows and has put up roadblocks that inhibit the growth of this sector. As I say in my Globalization book, the personal computer (PC) is incompatible with the the Communist Party (CP).

But if this lack of "flatness," or difference in comparative advantage, arises from political diversity, I suspect that the case of Japan illustrates the differences that arise culturally. ${ }^{12}$ Japan in 1980s and early 1990s aroused similar fears: that they would take over everything we were doing in the rich countries. The fears were differently premised and had little to do with Japan's huge size (for it is an island economy) or with Japan's "low" wages, which are the fears that arise regarding India and China. The fear of Japan instead had much to do with the nation's meteoric rise in world trade and performance just as India and China's dazzling performance does today. But, in the end, they could not master the financial sector, while retaining their prowess in manufacturing. The reason seems to be cultural. Excellence at design, attention to craftsmanship and meticulousness in attention to consumer satisfaction, belying the previous notion that Japan could only produce shoddy products, have led to continuing dominance at the upper end of quality production. But these qualities do not help you in fast-moving modern finance where dithering and dilatory responses mean that you lose to others whose

12 Culture, of course, is not immutable and changes over time, including in response to changing economic opportunities and challenges. But this does not mean that cultures are different at any point of time, yielding comparative advantage differences that imply that the world is not flat. 
responses are faster. For nearly two decades, Japan has faltered because its way of doing business has not given it comparative advantage in managing the financial sector. This has spilled over into macroeconomic failure as well. Now, Japan is busy addressing this issue by opening up to foreign banks and investment in its financial sector, hoping to learn through foreign infusion the different culture that the modern financial sector requires.

So, contrary to what is feared, there is no reason to think that comparative advantage is going to disappear: that the world is flat! Two further points need to be made. As my student Paul Krugman has emphasized, national competitiveness is a fallacious construct. If India and China have low wages, the exchange rate can adjust to offset that advantage; or, with fixed exchange rates, other (not so good) mechanisms will be triggered to adjust the trade balance and to have comparative advantage resurface. But there is also the important point that econometric studies on the location decisions of multinationals (when all industries are considered) typically show that factors other than cheap labor are important; concern about lower wages is simply a fetish.

Moreover, it is a mistake to think that, just because wages are low, the sheer size of the population of India and China will ensure that they will remain low despite rapid growth. All observers, whatever their political persuasion, are agreed that over two decades of two-digit growth in the four provinces on the East Coast of China have seen a rapid increase in the demand for labor whereas the kicking-in of the one-child policy and the slow influx of workers from the hinterland (partly because there are many obstacles put in the path of rural-urban migration by the authorities) have combined to raise wages and improve working conditions. Equally, in India, when the outsourcing of "long distance" or arm's-length services such as callanswer services is considered, the wages have been rising there too. In fact, if you look at the population in the age cohort for College, only about a tenth actually goes to College. Of that, still a smaller fraction studies in English. ${ }^{13}$ Of that a small fraction can speak English. Of that, again, a small fraction can speak English in a way we can understand. Yes, the queues out side call centers are big; but queuing does not guarantee that you can do the job that is necessary.

Then again, whereas my good friend Richard Freeman of Harvard University talks these days of the large numbers of engineers graduating in India and China, larger than those in US, this does not allow for quality of the education they have received. It will be many years before even a small

13 In fact, it was startling to see that the Government of Karnataka where India's Silicon Valley is located, passed legislation in September 2006, throwing out English from its public sector schools! Advertised as a measure aimed at helping the poor, it is in fact a dagger aimed at them: they want to learn English, but will not be able to, whereas the parents who can afford it will send their children to private schools or hire private tutors to teach English to their children. 
fraction of these will come up to snuff. Besides, there are lots of local tasks such as bridge repairs and road-building, and construction, which absorbs a gigantic fraction of these engineers; and in China, the stocks of engineers was badly depleted by the Cultural Revolution and a sizeable fraction of the current graduates must go toward rebuilding these stocks. In short, the alarmist interpretations and predictions of the growth of skilled personnel in China and India and of the threat it poses to rich-country jobs through diminished gains from trade, are to be seriously discounted. Our comparative advantage in skills-intensive jobs is by no means going to disappear in the foreseeable future.

\section{A DIFFERENT METAPHOR: KALEIDOSCOPIC COMPARATIVE ADVANTAGE}

But if comparative advantage is not dead - indeed it cannot die in the world as we know it - the real problem is that it has become volatile. Friedman's metaphor is wrong: the world is not flat any more than it was when the flatearthers of antiquity were challenged by Pythagoras in sixth century BC. The appropriate metaphor is different: the world is now characterized by what I call "kaleidoscopic comparative advantage."

As it happens, this volatility, or "knife-edge" property of specialization, where you have it today and you have lost it to a rival tomorrow and may then get it back the day after tomorrow, is itself due to the fact that almost no CEO in traded services and goods leads a comfortable life now. The "thick" margins of competitive advantage have practically disappeared from. When William of Orange and Queen Mary grew oranges in the greenhouses at Hampton Court, no one lost sleep in Haifa where the oranges could grow in nature in abundance. Today, the competitive margins have shrunk for several reasons that I identified 10 years ago in a review article in 1997 in The New Republic, titled "A New Epoch?" I described how the competitive margins had begun to shrink because, to cite some principal phenomena, multinationals could go today to many locations which therefore had access to their technology, interest rates were increasingly similar due to the growing integration of financial markets, many countries were building educational institutions where students could read the same textbooks as only in a few countries earlier, and students increasingly were studying abroad and acquiring technical know-how at the world level. At the same time, there were many countries at active play in the international markets today because trade barriers had been increasingly dismantled, either through reciprocal cuts in trade negotiations or due to unilateral actions inspired by the realization that protectionism was harmful to one's economic health.

Where the readers of Friedman are likely to think that competition comes from India and China, however, my analysis focuses on the fact that it can come from almost anywhere. CEOs, looking behind them, are very likely to see some rival 
stealing up on them. But that rival need not be from India or China. It can be from Brazil, from Poland, from France, indeed from a number of trading countries. But there is certainly going to be someone stealing up on you today; and you had better be on your toes. The competition today is knife-edge.

Two consequences follow. First, faced with this ferocity of competition, the temptation is great to ask for protection. But that is a difficult road to travel as policymakers rarely oblige. But then one can always ask for a different kind of protection: one can try to "level the playing field" by asking that the rivals from poorer countries and usually lower standards in labor et. al, be forced to raise them to our levels, so they do not get an "unfair" advantage. I.e. one can ask for "fair trade." To put it in terms of the flat world metaphor, the response to import competition can take the form of raising the cost of production of your rivals abroad, so that we do not have a flat world but rather we have firms under competitive pressure trying to flatten the world! It is what I call "export protectionism."

Second, it is a mug's game. Even if labor and domestic environmental standards were equalized to ours in the poor countries, this will never eliminate the problem of fierce competition today. It is like putting a finger in the dyke.

\section{COPING WITH KALEIDOSCOPIC COMPARATIVE ADVANTAGE REQUIRES SEVERAL POLICY AND INSTITUTIONAL CHANGES}

So, Friedman is wrong in suggesting that the world is flat and comparative advantage has disappeared relative to India and China, I am afraid. And so are the unions and other NGOs who think that raising standards elsewhere up to those in the rich countries (which incidentally vary among them and, in US, are nothing to write home about, for that matter) will moderate competition and lead to a more comfortable life.

What then should be our response to Globalization when it is characterized by rapidly shifting comparative advantages? The gains from trade are real; but the volatility requires institutional response and reconstruction of inherited ways of doing things.

\subsection{Security for Workers, No Longer through specific jobs}

If volatility is now a dominant fact of life, unions cannot expect to define security for their unskilled workers in terms of specific jobs. Specific jobs are increasingly subject to demise and disappearance. So, the unions must define security in terms of workers themselves. This means that the unions must now get active in getting their members to acquire the tools of mobility from one job to another. This requires that the unions must now go back to the old tenets of socialists such as G.D.H.Cole who emphasized the importance of educating the workers: I recall Ruskin College in Oxford which was doing 
just that. So, workers may enjoy, like many of us, sitting in front of television sets and drinking beer and eating potato chips as they watch soccer or baseball with frenzied attention. But they must be persuaded to go to a Union school on Saturday or Sunday when they can learn a language or computers or other skills for $2 / 3 \mathrm{~h}$ every week. This addition to their "portfolio of assets" will increase their chance of being able to go from a lost job to a new one.

In addition, if jobs are going to be less permanent than they have been, we must confront the fact that unskilled labor's wage profile over a lifetime showed a mild rise, an upward slope, because the firms tended to impart human capital on the job to workers who would stay in the job over long periods. Now, that wage profile is likely to be flatter because, faced with impermanence, the firm's incentive to add human capital to the unskilled workers it is employing currently is going to be reduced. ${ }^{14}$ This argument also calls for initiatives to add human capital through appropriate education for the unskilled workers today.

\subsection{Skilled Labor: Optimal Trajectories of Transition}

The same goes for skilled labor. Strangely enough, while the "skill premium" has grown, also due to technical change that economizes on unskilled labor but favors skilled labor, the fear of Globalization has spread even to the skilled who see their jobs being imperiled by the phenomenon. This alarm spread rapidly through the US when a radiologist US $X$-rays digitally to India to be read there: it was then assumed that all radiologists (and then doctors in all medical specialties) would lose their jobs. But the fact is that no radiologist has lost his job to date. The outsourcing has been largely to India and Australia where the time zone differences have made it possible to get $X$-rays read while the American doctors sleep or enjoy their weekends (so that these foreign firms are aptly called "nighthawks").

In fact, it is hard to think of a net loss of jobs in the skilled categories as technical change and shifting circumstances continually throw up demands for new skills. Thus, even if radiology were to be lost through outsourcing, can it be doubted that the spread of obesity has led to a vastly increased demand for doctors in diabetes and cardiology? Besides, the ageing of the population has led to a hugely increased demand for cosmetic surgery that is now spreading from women to men. I have betted that even Clint Eastwood will some day get a face lift, though I doubt if I and he will live long enough for me to win the bet!

The real problem again is how to facilitate the movement of the skilled from declining to rising skills. I have proposed that the professional associations, like

14 This implication of volatility of comparative advantage was noted by me in The New Republic article that I cited earlier. 
the American Medical Association, assist the process by working out "assisted trajectories of transition" so that if radiologists lose out, then they do not have to go back to the beginning and work for years to shift to the specialties rising in demand. Rather, the AMA would work with the doctors to see how the length of the transition path can be minimized.

\subsection{Education: Reducing Excessive Specialization}

Again, education, both at the university and less exalted institutions such as the Community College in US, and in vocational institutions, must ensure that the ratio of specialized to general technical education be shifted in favour of the latter. Thus, engineers should not spend the greatest amount of time learning mechanical engineering and the least amount of time on general engineering which would embrace more of chemical and electrical engineering, for instance. In the Soviet Union, where there was no change, engineers were trained for very specific specializations where they spent their lives in an inflexible job assignment in a rigidly planned economy. We now have the problem that we must educate people in skills that have no longer a guarantee of being in permanent demand, and hence they must be endowed with a good general base, a platform from which they can reassign them from obsolete skills to those in new demand.

\subsection{The Question of Ageing Societies}

I might add that, in ageing societies such as those in many parts of Europe, the ageing phenomenon creates both opportunities and problems. On the opportunity side, consider that it leads to new demands for a variety of medical skills: among them, cosmetic surgery which has witnessed a huge surge. Not merely are women having resort to these procedures; men are increasingly doing so. But, on the problems side, enabling people such as older doctors, where their skills such as radiology might be threatened by outsourcing, transiting to new skills can be quite difficult. If the demand for Professors of Economics were to fall off, and there were no tenure, and I lose my job at the age of 55, for example, I would hate to be told that there are a lot of opportunities for Professorships in Theoretical Physics: it is pretty well impossible for me to become a Professor of Theoretical Physics at that age! In some cases, therefore, the challenge of transiting to new skills will be daunting. It is clear, therefore, that one element of adjustment that might be useful is to make import-competition-related adjustment assistance amounts and time periods age-linked. ${ }^{15}$

15 Of course, the transition to new skills is a problem that can arise from domestic technical change and consumer demand shifts as well. But, as I argued in my 1988 book on Protectionism, MIT Press, citizens do think that an extra element of assistance is necessary when the 


\subsection{Differential Demographics: A Gray Peace Corps}

But I also see in modern demographics, and asymmetrical endowment of skills worldwide, an opportunity to find new and fulfilling jobs for the ageing skilled workers of the rich countries. Countries such as Germany and Italy are no longer reproducing themselves: their women no longer see themselves as manufacturing babies. At least two consequences follow.

First, these European countries find themselves in the same position as they were when the second World War had decimated their young men and they developed the gastarbeiter (guest-worker) programs. If properly managed, this provides an interesting opportunity for the poor countries with workers that cannot be gainfully employed to send them to the rich countries that have more jobs than people. I used this fact to advantage when asked on US television how I felt that Mrs. Sonia Gandhi, an Italian, might become India's Prime Minister. I ducked the issue by saying: "Italy is not reproducing itself; in about 30 years, a quarter of the Italian workforce is expected to be immigrants; of these, a large fraction will obviously be Indians; given the high rate of turnover of Italian Prime Ministers, I can therefore confidently expect that there will soon be an Indian Prime Minister of Italy; we will then have taken our revenge!"

Second, regarding skilled workers, the ageing population and retirements, and the difficult adjustment problems facing the old thanks to obsolescence of skills due to kaleidoscopic comparative advantage, in Europe and US can match the huge, unfilled needs of African nations for skills of virtually every type. As we train more Africans, most will surely leave to work in the rich countries: as I have often remarked, while Indians and Shirley MacLean believe in a multiplicity of lifetimes, we maximize our welfare in the current life like everybody else. Eventually, these Africans will return when political governance has improved, economic growth has taken root and social conditions (such as divorce legislation that matters much to the professional classes) have changed for the better.

In the meantime, we will long have glaring needs for skills in Africa. I have argued that these needs can be met by creating a Gray Peace Corps where retired doctors, agronomists, teachers, nurses, doctors, and people with many other skills can be sent for periods of two and more years at suitably high compensation to work in African countries. Again, therefore, supply and need can meet through cross-border flows, properly organized and managed, easing in turn the adjustment problems of ageing populations. 


\subsection{Labor Markets}

Then again, in a world of kaleidoscopic comparative advantage, with increased volatility in specialization, labor market flexibility in hiring and firing becomes important. When comparative advantage is lost, if workers cannot be laid off, the cost to the firm rises significantly. So, if the firms can invest abroad where labor can be fired when demand fails, the margin will shift in favor of investing abroad rather than at home. So, we will get the phenomenon, apparently observable in France and Germany with stringent restrictions or penalties on firing workers, that the French and German firms are competitive but they do not create jobs in their home countries. This seems to be the case also in Sweden: I have just read the Report by the Swedish Confederation of Industry which highlights this problem persuasively.

Again, when entire firms disappear and workers enter the search process, the question arises as to the optimal length of relief and assistance before the next job is found. Evidently, a safety net has to be provided, on both political and economic grounds. But if the workers are supported at high compensation rates and for long periods, the safety net may turn into a hammock, delaying beyond the optimal the provision of the assistance during the search process for new jobs.

\subsection{Innovation: From Basic Science to Engineering}

One final thought is necessary. Globalization today reflects knife-edge, volatile comparative advantage for several reasons which I have already detailed. But one important reason is that when firms go from basic science, which is largely unpatented, to engineering new products and processes which can be patented, the diffusion of that know-how is very swift today. Thus, software diffuses very rapidly; and intellectual property protection is sought merely with a view to getting royalties on what cannot be prevented from being diffused.

But when the Schumpeterian monopoly advantages that innovation brings are eroded rapidly today, in the globalized world, the only way to survive and prosper is to be continually innovative. Innovation policy then becomes part of the portfolio of policies to cope with globalization today.

So, I conclude with the observation that Globalization poses institutional and policy challenges that require a coherent and holistic treatment. The Netherlands can do no better than to reject the temptation to somehow muddle through: such an option is not a real option. Professor Tinbergen would have chosen the better path of looking the problems in the eye. 